\title{
Infrastructure sufficiency in meeting water demand under climate-induced socio-hydrological transition in the urbanizing Capibaribe River basin - Brazil
}

\author{
A. Ribeiro Neto ${ }^{1}$, C. A. Scott ${ }^{2}$, E. A. Lima ${ }^{3}$, S. M. G. L. Montenegro ${ }^{1}$, and J. A. Cirilo ${ }^{4}$ \\ ${ }^{1}$ Department of Civil Engineering, Federal University of Pernambuco, Recife, Brazil \\ ${ }^{2}$ School of Geography \& Development and Udall Center for Studies in Public Policy, University of Arizona, Tucson, USA \\ ${ }^{3}$ Campus Professora Cinobelina Elvas, Federal University of Piauí, Bom Jesus, Brazil \\ ${ }^{4}$ Academic Center of Agreste, Federal University of Pernambuco, Caruaru, Brazil
}

Correspondence to: A. Ribeiro Neto (alfredoribeiro@ufpe.br)

Received: 18 February 2014 - Published in Hydrol. Earth Syst. Sci. Discuss.: 7 March 2014

Revised: 7 August 2014 - Accepted: 7 August 2014 - Published: 8 September 2014

\begin{abstract}
Water availability for a range of human uses will increasingly be affected by climate change, especially in the arid and semiarid tropics. The main objective of this study is to evaluate the infrastructure sufficiency in meeting water demand under climate-induced socio-hydrological transition in the Capibaribe River basin (CRB). The basin has experienced spatial and sectoral (agriculture-to-urban) reconfiguration of water demands. Human settlements that were once dispersed, relying on intermittent sources of surface water, are now larger and more spatially concentrated, which increases water-scarcity effects. Based on the application of linked hydrologic and water-resources models using precipitation and temperature projections of the IPCC SRES (Special Report: Emissions Scenarios) A1B scenario, a reduction in rainfall of $26.0 \%$ translated to streamflow reduction of $60.0 \%$. We used simulations from four members of the HadCM3 (UK Met Office Hadley Centre) perturbed physics ensemble, in which a single model structure is used and perturbations are introduced to the physical parameterization schemes in the model (Chou et al., 2012). We considered that the change of the water availability in the basin in the future scenarios must drive the water management and the development of adaptation strategies that will manage the water demand. Several adaptive responses are considered, including water-loss reductions, wastewater collection and reuse, and rainwater collection cisterns, which together have potential to reduce future water demand by $23.0 \%$. This study demonstrates the vulnerabilities of the infrastructure system
\end{abstract}

during socio-hydrological transition in response to hydroclimatic and demand variabilities in the CRB and also indicates the differential spatial impacts and vulnerability of multiple uses of water to changes over time. The simulations showed that the measures proposed and the water from interbasin transfer project of the São Francisco River had a positive impact over the water supply in the basin, mainly for human use. Industry and irrigation will suffer impact unless other measures are implemented for demand control.

\section{Socio-hydrological transition}

One of the most important impacts of climate change occurs in water resources availability (Milly et al., 2008). Surface water and groundwater recharge may be directly affected by changes in rainfall and increases in air temperature that cause higher evapotranspiration rates. A direct consequence of changes in streamflow regimes is the impact on water supplies. This is expected to lead to decreased water quantity available for different uses, especially to guarantee food supplies in the arid and semiarid tropics (Bates et al., 2008). Climate change may also affect the function and operation of existing water infrastructure as well as water management practices (Kundzewicz et al., 2007). Conversely, adaptive water management through forward-looking planning and operation of infrastructure coupled with flexible demand 
management represents an important strategy to face climate change and variability (Short et al., 2012).

Infrastructure is planned, designed, and built considering future conditions of supply, demand, and variability. Supply under water-scarce conditions is determined by hydroclimatic and basin processes, especially surface water and groundwater flows, as well as water quality. It is increasingly recognized that forecasting future demand is strongly influenced not just by demographic trends but also by water allocation among different uses (e.g., cities, agriculture, and ecosystems), management practices (e.g., water use efficiency), pricing and supply/rationing regimes, and end-user awareness. In this paper, we address the concept of infrastructure sufficiency as the ability of water supply systems to reliably meet future demands given the uncertainty inherent in future supply-and-demand conditions. It is essential to assess supply-demand imbalances, particularly if they are projected to get progressively worse or if supply targets are not met for prolonged periods of time, causing economic, social, and environmental damage. The most appropriate method to estimate impacts is the use of scenarios run through global circulation models (GCMs). The GCM outputs are used as inputs to hydrological models, which calculate the streamflow in the basin. The combined use of mathematical models makes possible the estimate of the possible impact of streamflow reduction in water allocation, as can be seen in Condappa et al. (2009) and Vaze et al. (2011). Integration of the GCMs/hydrological models has been accomplished using different types of models such as VIC (Variable Infiltration Capacity) (Liu et al., 2010), Large Basin Hydrological Model (MGB-IPH) (Nóbrega et al., 2011), and DiCaSM (Distributed Catchment Scale Model) (Montenegro and Ragab, 2012), among others. A similar strategy involves the use of regional climate models (RCMs) nested within GCMs to improve the spatial resolution and to permit hydrological simulation in smaller basins (Akhtar et al., 2009; Driessen et al., 2010). The vulnerability of infrastructure systems - understood here as the inverse of sufficiency, i.e., the inability to meet demand targets - can also be evaluated using coupled or sequentially run models - e.g., GCMs, rainfall-runoff models, and simulation models (Cha et al., 2012; Matonse et al., 2013; Hall and Murphy, 2010) - and using different indices (resilience, reliability, vulnerability) for estimating the robustness of the systems (Matonse et al., 2013), water use to resource ratio (Hall and Murphy, 2010), and percentage of the demand not met.

While infrastructure function is determined by supplyand-demand conditions, over the medium and longer terms the presence of reliable infrastructure itself can increase demand. Thus, the understanding of socio-hydrology that we advance in this paper is a sequential and coevolutionary process of (a) human demand for water exceeding natural supply; (b) development of local-scale, low-cost infrastructure to enhance and stabilize supply; (c) demand growth based on supply enhancement; (d) recurring water scarcity and/or short-term supply insufficiency; and (e) infrastructure to capture extra-local sources of supply. Step (e) is often followed by (c) and (d), with further supply enhancement limited by local or non-local sources of supply. At this stage, adaptive management of demand, capture of losses, and reuse, among other strategies, become increasingly important for infrastructure sufficiency.

The bidirectional influences between supply (infrastructure) and demand (allocation, use) are in continual transition. A transition is a structural change in the way a societal system operates over the longer term (25-50 years), resulting from a coevolution of cultural, institutional, economical, ecological, and technological processes (Van der Brugge et al., 2005). Managing the transition can also entail the use of scenarios to deal with uncertainties, generating and sustaining societal pressure in political and market terms in order to safeguard the long-term orientation and goals of the transition process (Loorbach and Rotmans, 2010). To pursue this conceptual approach, a central question we intend to answer in this paper is, "can models and scenarios aid in evaluating infrastructure and its sufficiency, augmented by alternative strategies to manage socio-hydrological transition in a semiarid basin?"

This paper considers semiarid northeast Brazil, which is experiencing a reduction of water availability due to changes in the climate (Kundzewicz et al., 2007) as well as increases in human water demand for urban supply, irrigation, and other purposes. As such, this region is broadly representative of water-scarce regions globally that are facing increasing threats to water security (Scott et al., 2013). The Capibaribe River basin (CRB) has characteristics typical of Brazil's semiarid northeast, and it has experienced spatial and sectoral (agriculture-to-urban) reconfiguration of water demands. The economic growth in the interior of the basin combined with urbanization has stressed water security in terms of availability and quality. The release of domestic and industrial wastewater in the river plus land-use changes affect the water cycle in the basin, as evidence of growing human influence on water availability (Thompson et al., 2013; Savenije et al., 2014). These are the "forward" impacts of society on hydrology. On the other hand (hydrology impacts on society), dispersed human settlements in the CRB must be taken into account. Small communities are increasingly concentrating around infrastructural water supplies (groundwater, where available, but increasingly tanker-truck supplies during drier months and overextended drought periods). Together these constitute a socio-hydrological transition process that results from (a) hydroclimatic variability, (b) investment and assistance programs that may enhance but can also supplant local adaptive capacity, and (c) demographic trends that are already pronounced in Brazil.

Support programs are crucial to prevent rural populations from migrating to cities. Such programs include crop insurance (Garantia Safra), income transfer (Bolsa Família) and credit schemes (PRONAF) at the federal level, and Chapeu 


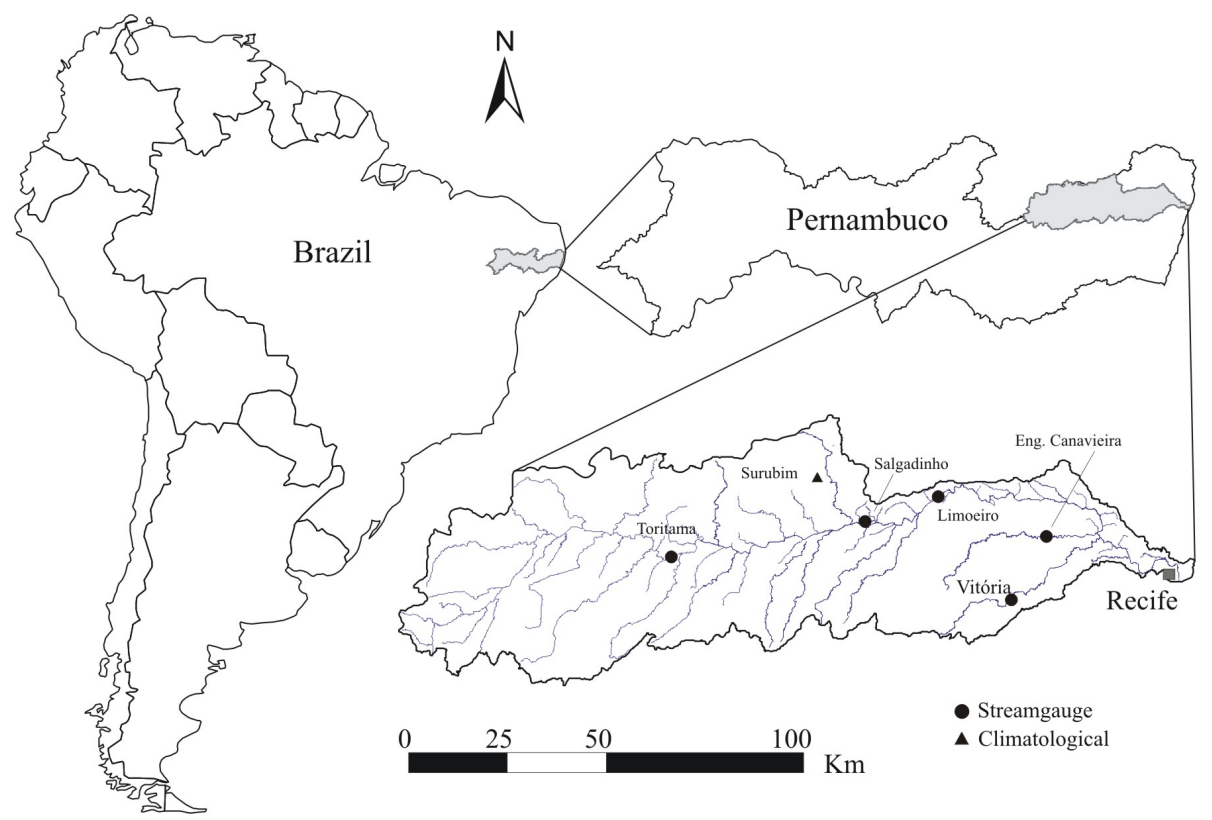

Figure 1. Capibaribe River basin.

de Palha and PRORURAL run by the Pernambuco state government. During the recent drought between 2011 and 2013, Pernambuco supported farmers and ranchers with subsidized inputs.

The strengthening of the water infrastructure in northeast Brazil, including Pernambuco state, in the last decades has increased the resilience of the water supply systems to face drought events and reduce the vulnerability to climate variability. The infrastructure projects involve construction of reservoirs, pipelines, and canals. Such solutions have been implemented in the Capibaribe River basin and Recife, the capital of Pernambuco state. Other projects are also planned to support water supply systems in Pernambuco.

The interbasin transfer project of the São Francisco River is the largest water infrastructure project in Brazil. Two canals will transport an average of $63.2 \mathrm{~m}^{3} \mathrm{~s}^{-1}\left(127.0 \mathrm{~m}^{3} \mathrm{~s}^{-1}\right.$ at maximum) from the river to four states of northeast Brazil. The average withdrawal is small when compared with water availability in the source basin $(3.4 \%)$. The project will take water to 12 million people, including regions that today are supplied by the CRB. The main objective of the project is to augment water supply in a manner that enhances local infrastructure. The northeast has a number of reservoirs for water supply where the loss by evaporation is very high resulting from the necessity of maximizing storage at high water levels. The water from the São Francisco River project may safeguard these supplies; i.e., the reservoirs may operate at lower levels with lower evaporation losses. The implications of the developments described in the last two paragraphs must be assessed in tandem with climate-change impacts.
The current analysis has been accomplished using three types of models: (1) climate model outputs of rainfall and air temperature for the IPCC emissions scenarios; (2) a hydrological model to estimate the discharge in the river; and (3) a network flow model for simulating the balance between water supply and water demand. The main objective of this study is to evaluate the infrastructure sufficiency in meeting water demand under climate-induced socio-hydrological transition in the CRB. The evaluation may be useful for planning and developing actions aiming to diminish the climatechange impact on the population and economic activities in the basin. At the same time, analyzing the flexibility of the water resources system for different parts of the basin may support the Secretaria de Recursos Hídricos e Energéti$\cos$ (SRHE), the principal state agency responsible for planning and management of water and energy infrastructure. Two of the authors have served in operational capacity with SRHE. In particular, the assessment presented here supports the Hydro-Environmental Master Plan of Capibaribe River further details are provided below.

\section{Methods}

\subsection{Study area}

The Capibaribe River basin $\left(7454 \mathrm{~km}^{2}\right)$ located in the state of Pernambuco in northeast Brazil has a west-east direction, with its headwaters in a semiarid region and its outlet section on the Atlantic Ocean coast (Fig. 1). For this reason, there are different types of soil, vegetation cover, climate, and relief along its extension. The uplands are characterized by shallow 


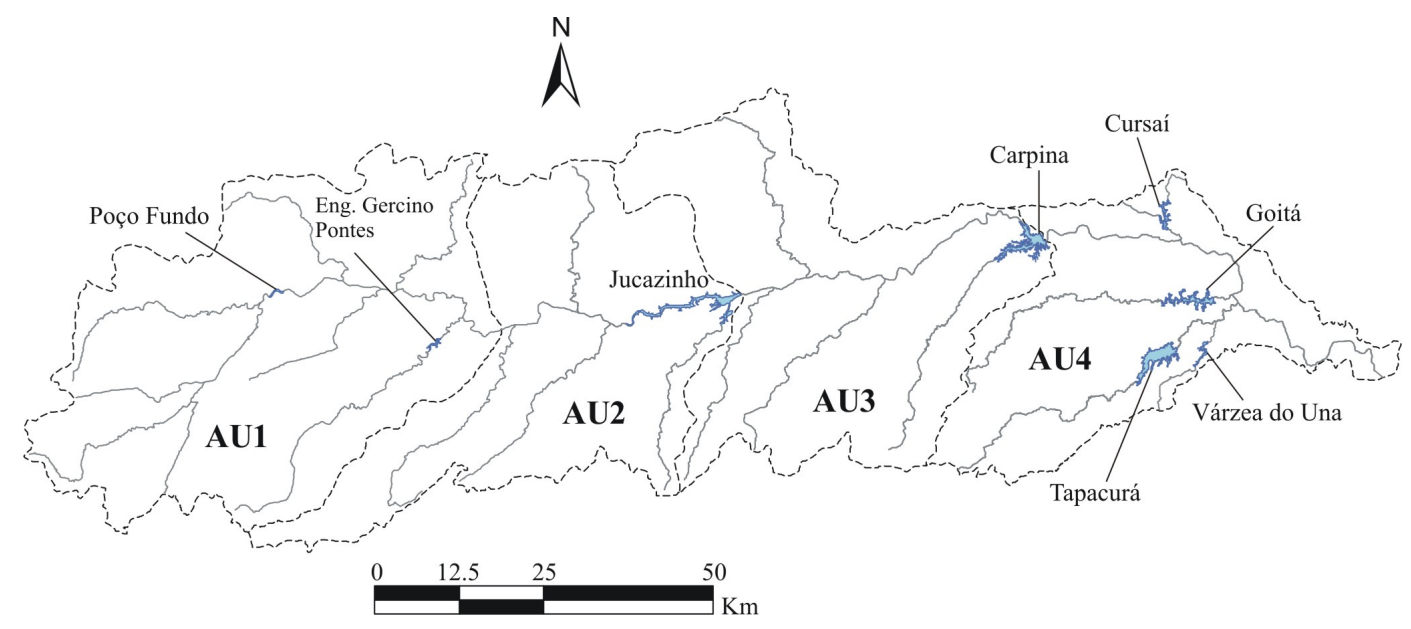

Figure 2. Reservoir locations and analysis units.

soils, Caatinga vegetation (thornscrub, cactus, and bunch grasses), and a semiarid climate with $550 \mathrm{~mm} \mathrm{yr}^{-1}$ of rainfall and mean air temperatures between 20 and $22^{\circ} \mathrm{C}$. The lowlands are characterized by deeper soils, Atlantic Forest vegetation, and a humid/sub-humid climate, with $2400 \mathrm{~mm} \mathrm{yr}^{-1}$ of rainfall and mean air temperature between 25 and $26^{\circ} \mathrm{C}$. The altitude in the basin varies from $0 \mathrm{~m}$ at the outlet section to $1199 \mathrm{~m}$ in the uplands. The main course of the Capibaribe River is $280 \mathrm{~km}$ long.

There are 42 municipalities completely or partially inside the basin and 26 urban or town centers of municipalities in the interior of the basin, including Recife, the capital of Pernambuco. The total population in the basin is 1.71 million, of which 0.76 million reside in Recife. The main water uses are human, industry, and irrigation, totalling $9.41 \mathrm{~m}^{3} \mathrm{~s}^{-1}$ of demand. The spatial distribution of the demand is influenced by the water availability; i.e., the greatest volumes withdrawn from the basin correspond to places closest to the lower Capibaribe River. There are two points in the basin with infrastructure for water transfer. In the central portion of the basin, there is a pipeline that transfers water to cities of the Ipojuca River basin $\left(0.683 \mathrm{~m}^{3} \mathrm{~s}^{-1}\right)$. In the lower part, the water supply system of the Recife metropolitan region receives water from a reservoir outside of the CRB $\left(0.455 \mathrm{~m}^{3} \mathrm{~s}^{-1}\right)$.

The CRB has eight reservoirs with storage capacities greater than 10 million $\mathrm{m}^{3}$ (MCM) each. The total capacity of the reservoirs is about $800 \mathrm{MCM}$. All the reservoirs are used for water supply, and four of them are also used for flood control (Jucazinho, Carpina, Tapacurá, and Goitá). Table 1 shows the characteristics of each reservoir.

The Hydro-Environmental Master Plan of Capibaribe River (Pernambuco, 2010) encompasses a diagnosis with hydrological, environmental, and socio-economic studies. Two scenarios have been analyzed: "business as usual" and "sustainable". The results aided the setup of investment plans to the basin. The basin has been divided into four regions
Table 1. Characteristics of the reservoirs.

\begin{tabular}{lrrl}
\hline Name & $\begin{array}{r}\text { Capacity } \\
\left(10^{6} \mathrm{~m}^{3}\right)\end{array}$ & $\begin{array}{r}\text { Drainage } \\
\text { area }\left(\mathrm{km}^{2}\right)\end{array}$ & $\begin{array}{l}\text { Closest stream } \\
\text { gauge }\end{array}$ \\
\hline Poço Fundo & 27.75 & 926.00 & Toritama \\
Eng. Gercino Pontes & 13.60 & 384.00 & Toritama \\
Jucazinho & 327.04 & 4772.00 & Limoeiro \\
Carpina & 270.00 & 6000.00 & Limoeiro \\
Cursaí & 13.00 & 57.00 & Eng. Canavieira \\
Goitá & 52.00 & 450.00 & Eng. Canavieira \\
Tapacurá & 94.20 & 360.00 & Vitória \\
Várzea do Una & 11.57 & 38.00 & Vitória \\
\hline
\end{tabular}

(analysis units - AUs) according to their climatological, hydrological, and socio-economic characteristics. Figure 2 shows the boundaries of each AU, and the reservoirs are indicated in Table 1.

The temporal variation of water demand is influenced by the growth of the population and the economy in the municipalities of the basin. During the 2000s the average annual water demand growth rate $(4.34 \%)$ followed social and economic factors such as the annual growth rate of the gross domestic product (GDP, $12.36 \%$ ), annual population growth $(1.38 \%)$, agriculture area growth $(6.58 \%)$, human development index improvement $(1.00 \%)$, and increased pollutant load released into the river (5.47\%) (Pernambuco, 2010). These factors are strongly influenced by the development of textile, sugar, and ethanol industries. The main irrigated crops are sugarcane in the analysis unit AU4, and vegetables in the analysis unit AU3.

During this period the increase in water availability resulting from improvement of the water infrastructure was lower than demand growth. At the same time, groundwater availability is significant only in AU4. The basin overlies crystalline-rock aquifers over virtually its entire area; only AU4 presents a sedimentary aquifer. The groundwater 
availability in AU1, AU2, and AU3 corresponds to $3.73 \%$ of the groundwater availability in AU4 $\left(1.257 \mathrm{~m}^{3} \mathrm{~s}^{-1}\right)$.

In northeast Brazil, many families live in the interior with limited access to water for drinking, cooking, and hygiene. These families live far from the systems of water supply. According to Pernambuco (2010), there are 111796 people in such conditions in the CRB ( $6.55 \%$ of the total population). During periods of severe droughts, as the northeast faced in 2011-2013, this population is supplied with water by tanker trucks and, in some cases, collecting water daily from springs and small reservoirs, generally by women and children, often over long distances. In addition to this, wells and cisterns are the most common water collection and storage systems in the region. Nongovernmental organizations supported by the federal government have installed about 500000 cisterns in northeast Brazil since 2003. The cisterns in the northeast have storage capacities varying between 7 and $16 \mathrm{~m}^{3}$, representing an availability of 50 $\mathrm{Lday}^{-1}$ during 140-300 days, assuming they are full of water at the end of the rainy season.

Precipitation in the AUs reduces from east to west, and the potential evapotranspiration increases in the same direction (Table 2). These characteristics contribute to the low runoff in AU1, AU2 and AU3 and high runoff in AU4. The soil type and geology in the basin also contribute to the spatial variability of runoff. The basin is predominantly over the crystalline basement (shallow soil and rock near the surface). The exception is the presence of sedimentary areas in AU4. The low storage capacity of the soil hinders the stabilization of the flow, resulting in intermittent rivers in the uplands of the basin.

\subsection{Data}

The mean rainfall in the basin has been calculated using data from 85 rain gauges of the hydrometeorological network of the National Water Agency (ANA) and Institute of Technology of Pernambuco (ITEP). The rainfall measured was used to assess the rainfall of the climate model as well as used in the calibration of the parameters of the hydrological model.

Scenarios under climate change are derived from Chou et al. (2012), who used the output data of the GCM HadCM3 (UK Met Office Hadley Centre) as the boundary condition in simulations of the regional climate model ETA-CPTEC (ETA version of the Brazilian Center for Weather Forecasts and Climate Studies). Using ETA-CPTEC and HadCM3 models, Chou et al. (2012) simulated rainfall, air temperature, relative humidity, and other climatological variables for the periods 1960-1990, 2010-2040, 2040-2070, and 2070-2100. The CO2 concentration in the base condition (1960-1990) is $330 \mathrm{ppm}$, whereas the future projections use the IPCC SRES A1B scenario. Chou et al. (2012) assert that there are two ways of estimating uncertainties in model simulation. One way is through the multimodel ensemble method. An advantage of this method is that a wide variety of model designs and configurations form the ensemble. The other
Table 2. Climatological characteristics of the analysis units (AUs).

\begin{tabular}{lrc}
\hline Unit & $\begin{array}{r}\text { Precipitation } \\
\left(\mathrm{mm} \mathrm{yr}^{-1}\right)\end{array}$ & $\begin{array}{c}\text { Potential } \\
\text { evapotranspiration } \\
\left(\mathrm{mm} \mathrm{yr}^{-1}\right)\end{array}$ \\
\hline AU1 & 579.1 & 1700 to 1850 \\
AU2 & 621.5 & 1650 to 1900 \\
AU3 & 842.2 & 1550 to 1800 \\
AU4 & 1228.1 & 1500 to 1700 \\
\hline
\end{tabular}

method follows the perturbed physics ensemble (PPE) approach, which is designed to quantify the modeling uncertainty in the simulation or projections of climate that depends on the way processes are represented in the model, i.e., in their physics parameters. Chou et al. (2012) used four members of the HadCM3 perturbed physics ensemble, in which a single model structure is used and perturbations are introduced to the physical parameterization schemes in the model. The first member is the standard model structure (CTRLcontrol), and the other ones are perturbations of the physical parameterization schemes used to produce variants of the same model (LOW, MIDI and HIGH). In our study, the analysis used the four members.

The ETA-CPTEC/HadCM3 runs presented bias for rainfall and air temperature. Both variables are generally underestimated when compared with the observed values. It is usually necessary to correct these data before using them in a study. The bias correction was made using cumulative distribution functions (CDFs) according to Bárdossy and Pegram (2011). We chose the simplest form of bias correction for air temperature. The mean bias is added to the model data after calculating the bias for each month of the climatological year (Berg et al., 2012).

The calibration of our hydrological model takes into account the stream gauge discharges. The ANA hydrometeorological network has three stream gauges in the main stem of the Capibaribe River and two in tributaries (shown in Fig. 1). The air temperature for calculation of potential evapotranspiration (PET) is measured in the climatological station at Surubim (also shown in Fig. 1). The PET has been estimated using the Thornthwaite method. This method uses only air temperature in its formulation, besides a factor that varies according to month and local latitude.

The Hydro-Environmental Master Plan of Capibaribe River (Pernambuco, 2010) exhibits the water uses, the volumes withdrawn from the reservoirs, and the characteristics of the reservoirs. This information is used in the network flow model. 


\subsection{Modeling infrastructure vulnerability}

\subsubsection{Hydrological model}

Rainfall and air temperature may be used to estimate the discharge in the Capibaribe River in the future using a hydrological model. MODHAC (the Portuguese acronym for "SelfCalibrated Hydrological Model") is a rainfall-runoff lumped model, whose input variables are mean rainfall and potential evapotranspiration (Lanna, 1997). MODHAC is similar to other models widely used for synthetic runoff generation such as Soil Moisture Accounting Precedure (SMA) present in the HEC-HMS model (HEC-HMS, 2000), and SMAP present in the MIKE 11 model (MIKE 11, 2009) and Tank model (Sugawara, 2012). All these models, including MODHAC, use reservoirs which represent the main processes responsible for rainfall-runoff transformation: interception, evapotranspiration, and runoff generation, i.e., determination of the volume of water that will either be infiltrated into the soil or flow on the surface. The results of MODHAC in Brazilian semiarid watersheds encourage its use in similar regions, like the CRB. The model has 14 parameters that can be calibrated automatically using four options of objective functions. In addition, MODHAC can run monthly time step simulations (suitable for this study), and it needs few input data (rainfall and PET).

\subsubsection{Network flow model}

A network flow model may be used for optimal basin-wide water allocation. This ensures that water is allocated according to physical, hydrological demands and institutional aspects of river basin management. Network flow models represent the water resources system using nodes and links. The nodes represent point elements such as reservoirs, demands, interbasin exchange and confluences, whereas links between two nodes represent river branch, pipelines, canals, and other similar elements. Each node has a cost per flow unit that influences the volume of water that will pass through it. The model algorithm seeks to minimize the total cost of the network using optimization techniques such as linear programming.

One of the most widely used network flow models is MODSIM (Labadie, 1995), developed at Colorado State University. MODSIM has been applied to a number of complex river basin systems such as the Sirvan basin in Iran (Shourian et al., 2008). The water allocation in the present study was done using the Acquanet model (Porto et al., 2003). This model was essentially constructed based on the structure of MODSIM. Acquanet has an interface of communication with the user and a database to store the information of the network flow.

The network model needs information of volume of water demand, operation rules and priority of demand. This information was obtained from the Hydro-Environmental Master
Plan of the Capibaribe River basin (Pernambuco, 2010). The order of priorities of demands is human, industry, and irrigation. In addition, the input discharge entering in each reservoir is calculated with MODHAC, and the evaporation in the reservoirs is calculated using air temperature.

The evolution of the water demand took into account different factors: population growth for human use, GDP for industry demand, and growth of irrigated area for irrigation demand. The Brazilian Institute of Geography and Statistics (IBGE) projects that Brazilian population will achieve the maximum in 2042 (228.4 million) and in 2060 will be 218.2 million inhabitants. In 2100, according to Department of Economic and Social Affairs (United Nations), the Brazilian population will be 194.5 million inhabitants. The population growth was the constraint to avoid the increasing of industry and irrigation water demand by the end of the century. We assume that both increase by 2040 and remain constant until 2100 , considering that the population will not grow after 2040 .

The change of the water availability in the basin in the future scenarios must drive the water management and the development of adaptation strategies that will manage the water demand. Three hypotheses have been considered:

- Reduction of water loss in the supply system. Today the loss is $55 \%$. This value may reduce to $25 \%$ with programs of improvement of the water supply network.

- Increasing of the return flow of water from domestic use. Today the value is $20 \%$ due to the limited wastewater collect system. The Pernambuco state government plans to improve the system, and it may mean an increasing of the return flow of water to $80 \%$.

- Implementation of cisterns for rainwater collection to supply water for the sparse populations.

These measures may reduce by about $23.0 \%$ the volume of water demand.

The environmental flow exhibited in the HydroEnvironmental Master Plan of the Capibaribe River was used in the network flow simulation. This discharge is considered only in UA4 because it is the perennial reach of the river. The reservoirs, demands, channels, and water facilities are represented in Acquanet using links and nodes as can be seen in Fig. 3. The discharge $\left(4 \mathrm{~m}^{3} \mathrm{~s}^{-1}\right)$ from the São Francisco River project is linked to human demands in the analysis units 1, 2, and 3 (Pernambuco, 2010).

\section{Results}

\subsection{Hydrological simulation}

MODHAC has been calibrated by using monthly time step in the four stream gauges from different parts of the basin 
Table 3. Model calibration at the stream gauges.

\begin{tabular}{lrccccccr}
\hline \multirow{2}{*}{ Name } & Drainage & \multicolumn{3}{c}{ Calibration } & & \multicolumn{3}{c}{ Validation } \\
& area $\left(\mathrm{km}^{2}\right)$ & Period & NS & $\Delta V(\%)$ & & Period & NS & $\Delta V(\%)$ \\
\hline Toritama & 2459.0 & $1973-1982$ & 0.8348 & 2.6 & & $1983-1990$ & 0.7669 & -31.1 \\
Limoeiro & 5596.0 & $1973-1982$ & 0.7241 & -2.0 & & $1983-1990$ & 0.6723 & -11.7 \\
Eng. Canavieira & 312.0 & $2000-2009$ & 0.7677 & 7.3 & & $2010-2013$ & 0.6497 & 6.4 \\
Vitória & 263.0 & $1985-1999$ & 0.8153 & -12.0 & & $2000-2009$ & 0.5892 & 45.4 \\
\hline
\end{tabular}

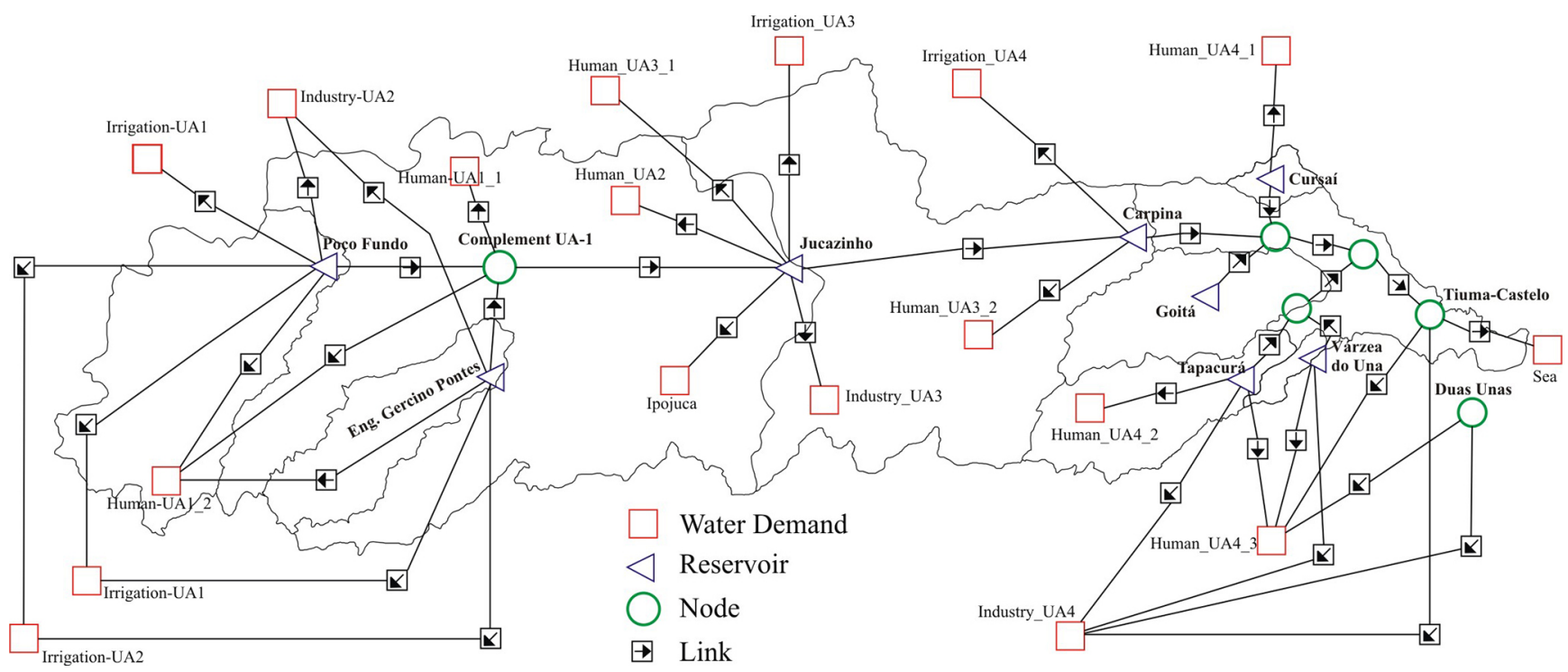

Figure 3. System representation in Acquanet.

according to the climatological characteristics: one in the upper basin, one in the middle basin, and two in the lower region (Fig. 1). Two periods of time were used, one for calibration and one for validation. Evaluation of the model calibration considers Nash-Sutcliffe coefficient (NS) and volume error $\left(\Delta V=\left(\sum Q_{\text {cal }}-\sum Q_{\text {obs }}\right) / \sum Q_{\text {obs }}\right)$. Table 3 exhibits the periods used in the calibration and validation, the drainage area, and values of the criteria (Nash-Sutcliffe and volume). The different periods of time are owing to the construction of reservoirs along the $\mathrm{CRB}$ at different times from the mid-1980s onwards. All the stream gauges had a good performance considering the Nash-Sutcliffe coefficient. Two sites exhibited high values for volume error in the validation (Toritama and Vitória).

The input streamflow in each reservoir is calculated using the set of parameters from the closest stream gauge according to Table 1 . We consider that the drainage area of the reservoir is hydrologically similar to the drainage area of the stream gauge. To evaluate this hypothesis, the model has been applied in a drainage area of a stream gauge (Salgadinho $-4923.0 \mathrm{~km}^{2}$ ) nested in the Limoeiro stream gauge. The set of parameters was the same calibrated at Limoeiro, and the period is from 1984 to 1992. The value of NS was 0.7540 and the volume error $1.1 \%$. The result of the calibration/validation and the simulation at Salgadinho encourages the use of the model to estimate the input streamflow in the reservoirs of the CRB.

Applying the set of MODHAC parameters using the rainfall and air temperature for the different time slices, it is possible to observe the impact on the streamflow at the outlet section of the Capibaribe River. The scenarios (corresponding to the four members) exhibited mean annual streamflow of $22.61 \mathrm{~m}^{3} \mathrm{~s}^{-1}$ (1960-1990), $19.44 \mathrm{~m}^{3} \mathrm{~s}^{-1}$ (2010-2040), $14.67 \mathrm{~m}^{3} \mathrm{~s}^{-1}$ (2040-2070), and $9.09 \mathrm{~m}^{3} \mathrm{~s}^{-1}$ (2070-2100). The concept of elasticity is a good way of evaluating the sensitivity of long-term streamflow to changes in long-term rainfall. According to Chiew (2006), the rainfall elasticity of streamflow is defined as the proportional change in mean annual streamflow divided by the proportional change in mean annual rainfall. Considering 1960-1990 as the reference baseline, the elasticity of the Capibaribe River can be estimated for the time slices (average of four members): 3.69 (2010-2040), 2.35 (2040-2070), and 2.39 (2070-2100). 

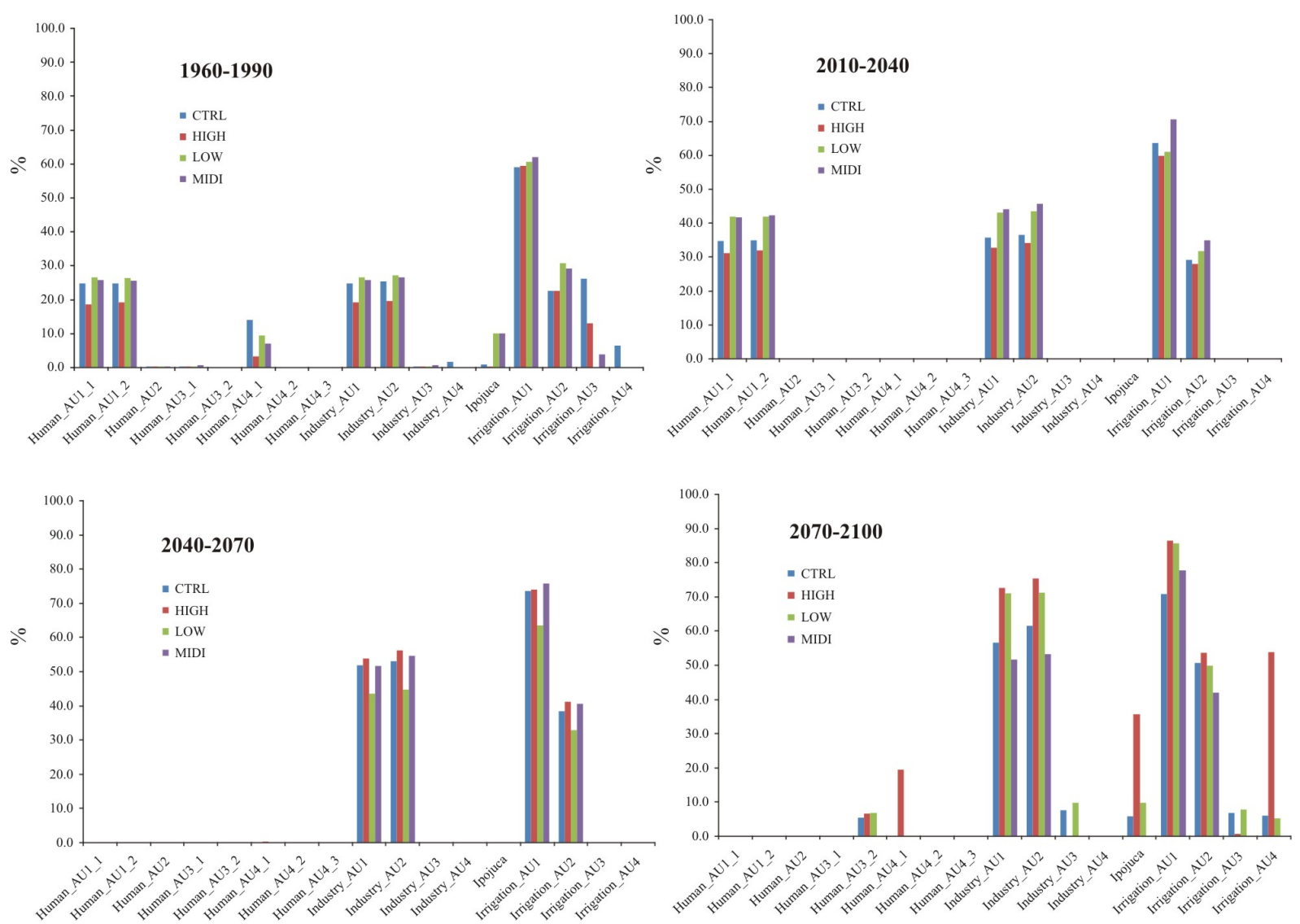

Figure 4. Percentage of time with demand not met for different time slices and PPE runs.

\subsection{Network flow simulation}

There were 16 simulations using Acquanet: four members running four time slices. The present period (1960-1990) simulation corresponds to a volume of water supply equal to $7.59 \mathrm{~m}^{3} \mathrm{~s}^{-1}$ (average of four members). This period did not have water from the São Francisco project because the construction finishes in 2015. The volume of water supply had little variation in the following periods to $6.63 \mathrm{~m}^{3} \mathrm{~s}^{-1}(2010$ 2040), $7.67 \mathrm{~m}^{3} \mathrm{~s}^{-1}$ (2040-2070), and $6.99 \mathrm{~m}^{3} \mathrm{~s}^{-1}$ (20702100). The 17 demands were assessed calculating the percentage of time corresponding to the demand not met by the water from reservoirs (Fig. 4). The code of each demand may be used to identify its location in the Fig. 3.

\section{Discussion}

The process of calibration and validation of the rainfallrunoff model used evaluation statistics, which exhibited adequate values, excluding volume error for validation periods at stream gauges Toritama and Vitória. Despite the unsatisfactory values of volume error, the NS values were adequate at these stream gauges.
The IPCC SRES scenario has been used to evaluate the impact of climate change on the water supply in the CRB. The results indicate that the mean streamflow of the Capibaribe River decreases significantly in the time slices 2040-2070 and 2070-2100. The reduction of rainfall and mean streamflow has also been verified in other basins of northeast Brazil located in semiarid regions, using the same IPCC SRES scenarios. Milly et al. (2005), for example, found a reduction of $-20 \%$ in runoff for northeast Brazil, using an ensemble of 12 climate models. Montenegro and Ragab (2012) have simulated the Tapacurá River basin, a tributary of the Capibaribe River, using the low-emission (B1) scenario and found a reduction of $-20 \%$ in surface flow for the time span 20702100. Marengo et al. (2009) also identified a reduction of rainfall in northeast Brazil using three RCM nested within the HadAM3P global model. Fung et al. (2011) verified the change in runoff in a world 2 and $4{ }^{\circ} \mathrm{C}$ warmer. Ensembles of GCMs runs for SRES A1B scenario from 1930 to 2079 were used. According to Fung et al. (2011), the ensemble-average changes in mean annual runoff in northeast Brazil will reach $-40 \%\left(+2{ }^{\circ} \mathrm{C}\right)$ and $-80 \%\left(+4{ }^{\circ} \mathrm{C}\right)$. The air temperature change estimated in the $\mathrm{CRB}$ is $+3^{\circ} \mathrm{C}$ with a corresponding runoff reduction of $-60 \%$ (average of four members). 
The results indicate high reduction of rainfall and, hence, reduction in mean streamflow and in the volume of water supplied for industry and irrigation in the CRB. Two factors can explain the sensitivity of the CRB to IPCC scenarios. First, part of the CRB is located in a semiarid area, which is expected to suffer more severe impact than other regions. On the other hand, the high population density and the water demand have as a consequence higher pressure on the water availability.

The elasticity of the CRB exhibited values that indicate high sensitivity to changes in the rainfall. In other words, small changes in rainfall may mean a high reduction in streamflow. The elasticity found by Chiew (2006) in catchments of Australia is about 2.0-3.5 (observed in about 70\% of the 219 catchments analyzed). These values are similar to the elasticity presented by the CRB in the time slices of climatic scenarios. Chiew (2006) observed that streamflow is more sensitive to rainfall in drier catchments, which partially is in accordance with the CRB. Scenarios of either reduction of rainfall or even change in the time distribution of rainfall can make an impact on the water supply in the CRB.

The simulation of water allocation in the network flow model for the baseline period shows stress in the supply mainly in the analysis units AU1 and AU2 (stress for human use included). The adaptation strategies for demand management tested in the network flow model showed that the stress continues in the period 2010-2040 due to the population growth. After that, the human demand decreases and there is a better balance between availability and demand. The problem stays for industry and irrigation because there was no control of these demands. The simulations showed that the measures proposed and the water from the São Francisco project had a positive impact over the water supply in the basin, mainly for human use. Industry and irrigation will suffer impact unless other measures are implemented for demand control.

It was verified that the range of values among the members of the climate model is greater for the streamflow than for water allocation. In the period 2070-2100, for example, the MIDI member streamflow is $156 \%$ greater than the HIGH member streamflow. For the same period and members, the variation is $15 \%$ in the water supply. These simulated results are attributable to water that is projected to come from the interbasin transfer project of the São Francisco River. These results show that the objective of the São Francisco project, to augment water supply in a manner that enhances local infrastructure, is reached in the CRB. That is the kind of positive impact expected by analysts that assessed the project (Pena de Andrade et al., 2011).

The reduction of water supply in the climate scenario has also been verified by Vaze et al. (2011) in Australia using 15 IPCC AR4 GCMs. Two hydrological models and a river system model were used to estimate water availability for historical (1895-2006) and future (2030) rainfall. The change of the diversion for irrigation varies between -27 and
$+21 \%$ depending on the GCM and hydrological model (the median value is about $-6 \%$ ). By the end of the 21 st century and considering the tendency for 2030 , the change estimated by Vaze et al. (2011) could meet the values obtained in the CRB.

\section{Conclusions}

The integration of three models made it possible to evaluate the impact of streamflow reduction in the Capibaribe River basin water supply due to possible climate-change scenarios and evaluate the impact of measures aiming to manage the water demand and the rational water use in the basin. The ETA-CPTEC-HadCM3 coupled climate models were used to estimate rainfall and air temperature in the CRB. Rainfall and air temperature exhibited values underestimated when compared to the observed data. The methods used for bias correction presented results appropriate for hydrological simulation. The MODHAC hydrological model adequately represented the streamflow in the $\mathrm{CRB}$, and has been used to represent the inflow discharge in each reservoir that comprises the water supply system in the basin. The use of a RCM instead of a GCM is more appropriate to represent the rainfall-runoff transformation in a basin with the dimensions of the CRB.

Hydroclimatic impacts on water resource systems' ability to meet multiple demands is of growing concern globally, with climate change and variability coupled with fluctuating demands. Adaptation measures to ensure water supply in a world under change require demand-side as well as supplyside strategies (Bates et al., 2008). Supply-side strategies involve increases in storage capacity, abstraction from water courses, and water transfers. The investment in water facilities, for example, is one of the strategies adopted by China to develop effective adaptation to climate change, natural disasters, and food security (Li, 2012). Demand management improves water use efficiency, water rights, effective regulation enforcement, and pollution control (Cheng and $\mathrm{Hu}, 2012$ ). Until the 1990s, northeast Brazil focused on the construction of small reservoirs and drilling wells in the crystalline rock. However, weak water management policies proved ineffective in matching demand with variable water availability. In the late 1990s, a new policy regime was implemented by Brazilian states with the support of the federal government and the law 9433/1997, which establishes the national water resources policy. The states were able to develop actions for water use control (permits and water abstraction charges), water resources master plans for the basins and states, creation of an institutional framework for water management, and programs for water facilities construction, all of which we consider more conducive to demand management.

The combination of infrastructure development and improvement of water management policies that anticipate hydroclimatic impacts, such as those modeled in this paper, 
may result in effective climate-change adaptation measures. Similar processes have been described for Australia by Short et al. (2012) and for developing countries by Mujumdar (2013). Hydrological and water resources models are tools able to simulate both the effectiveness of infrastructures and the adoption of water management policies in a basin impacted by the climate change.

On the other hand, the socio-hydrological transition underway shifts water demand in ways that can be considered another driving force in the process of increasing the water deficit. At the same time, sustained economic growth in the basin will demand an increasing volume of water. Thus, both climate change and water demand may lead to a water stress condition in the CRB. In a scenario with lower water availability, actions to overcome deficits into the water balance will be necessary. The adaptation for this condition requires a combination of diverse solutions in an integrated manner: construction and use of cisterns for human supply in dispersed population and desalination of water drawn from wells; family agriculture with short harvesting cycle, to take advantage of the water of surface reservoirs before losses by evaporation; construction and use of reservoirs with smaller water surface, and even underground dams; integration of large water sources using large main water systems to supply the cities and for development of irrigated agriculture; use of water saving technologies in agriculture, industry, and domestic use; and reuse of wastewater.

The simulation may be useful for transition management in basins under strong water stress, like the CRB. The measures and strategies could be tested using regional climate models, hydrological models, and allocation models. The next master plans in the Capibaribe River basin may consider the use of modeling to assess climate-change scenarios with the objective of evaluating strategies for mid- and longterm management. The results of the simulations showed that industry and irrigation will be at risk by the end of the 21 st century even with the use of water from the São Francisco project.

Uncertainties are inherent in analyses involving impact of climate change. Despite the use of the perturbed physics ensemble in the simulations, it is important to use other models with performances as good as HadCM3 for the simulation of base conditions in order to diminish the uncertainties related to the GCM output. The reliability of the results may be related to the number of GCMs used in the analysis, and it is also possible to associate a confidence interval with the rainfall change. This must be done in the next steps of the research. Despite the necessity of improving the reliability of the results, we can conclude that the combined use of mathematical models can aid the evaluation of the effectiveness of measures for socio-hydrological transition management. Modeling also shows the vulnerabilities of the system, such as the elasticity of the Capibaribe River, as well as indicating which parts of the basin are more vulnerable to changes.
Acknowledgements. The authors acknowledge the Brazilian Research Network on Global Climate Change (Rede CLIMA), the Brazilian National Council for Scientific and Technological Development (CNPq), and the Inter-American Institute for Global Change Research (IAI, project CRN3056, which is supported by the US National Science Foundation grant GEO-1128040).

Edited by: M. Sivapalan

\section{References}

Akhtar, M., Ahmad, N., and Booij, M. J.: Use of regional climate model simulations as input for hydrological models for the Hindukush-Karakorum-Himalaya region, Hydrol. Earth Syst. Sci., 13, 1075-1089, doi:10.5194/hess-13-1075-2009, 2009.

Bárdossy, A. and Pegram, G.: Downscaling precipitation using regional climate models and circulation patterns toward hydrology, Water Resour. Res., 47, 1-18, 2011.

Bates, B. C., Kundzewicz, Z. W., Wu, S., and Palutikof, J.: Climate change and water, Technical Paper of the Intergovernmental Panel on Climate Change, IPCC Secretariat, Geneva, 200 pp., 2008.

Berg, P., Feldmann, H., and Panitz, H. J.: Bias correction of high resolution regional climate model data, J. Hydrol., 448-449, 8092, 2012.

Cha, D., Lee, S., and Park, H.: Investigating the vulnerability of dry-season water supplies to climate change: a case study of the Gwangdong reservoir drought management system, Korea, Water Resour. Manage., 26, 4183-4201, 2012.

Cheng, $\mathrm{H}$. and $\mathrm{Hu}$, Y.: Improving China's water resources management for better adaptation to climate change, Climatic Change, 112, 253-282, 2012.

Chiew, F. H. S.: Estimation of rainfall elasticity of streamflow in Australia, Hydrolog. Sci. J., 51, 613-625, 2006.

Chou, S. C., Marengo, J. A., Lyra, A. A., Sueiro, G., Pesquero, J. F., Alves, L. M., Kay, G., Betts, R., Chagas, D. J., Gomes, J. L., Bustamante, J. F., and Tavares, P.: Downscaling of South America present climate driven by 4-member HadCM3 runs, Clim. Dynam., 38, 635-653, 2012.

Condappa, D., Chaponnière, A., and Lemoalle, J.: A decisionsupport tool for water allocation in the Volta Basin, Water Int., 34, 71-87, 2009.

Driessen, T. L. A., Hurkmans, R. T. W. L., Terink, W., Hazenberg, P., Torfs, P. J. J. F., and Uijlenhoet, R.: The hydrological response of the Ourthe catchment to climate change as modelled by the HBV model, Hydrol. Earth Syst. Sci., 14, 651-665, doi:10.5194/hess-14-651-2010, 2010.

Fung, F., Lopez, A., and New, M.: Water availability in $+2{ }^{\circ} \mathrm{C}$ and $+4{ }^{\circ} \mathrm{C}$ worlds, Philos. T. Roy. Soc. A, 369, 99-116, 2011.

Hall, J. and Murphy, C.: Vulnerability Analysis of Future Public Water Supply Under Changing Climate Conditions: A Study of the Moy Catchment, Western Ireland, Water Resour. Manage., 24, 3527-3545, doi:10.1007/s11269-010-9618-8, 2010.

HEC-HMS - Hydrologic Modeling System: Technical Reference Manual, US Army Corps of Engineers, Davis, USA, 149 pp., 2000 . 
Kundzewicz, Z. W., Mata, L. J., Arnell, N. W., Döll, P., Kabat, P., Jiménez, B., Miller, K. A., Oki, T., Sen, Z., and Shiklomanov, I. A.: Fresh water resources and their management, in: Climate Change 2007: impacts, adaptation and vulnerability, edited by: Parry, M. L., Canziani, O., Palutikof, J., van der Linden, P., and Hanson, C., Cambridge University Press, Cambridge, UK, 173210, 2007.

Labadie, J.: MODSIM: River Basin Network Flow Model for conjunctive stream-aquifer management, Program User Manual and Documentation, Colorado State University, Fort Collins, 1995.

Lanna, A. E.: MODHAC - Self Calibrated Hydrological Model, User's manual, Hydraulics Research Institute - Federal University of Rio Grande do Sul, Porto Alegre, 54 pp., 1997.

Li, S.: China's huge investment on water facilities: an effective adaptation to climate change, natural disasters and food security, Nat. Hazards, 61, 1473-1475, 2012.

Liu, Z., Xu, Z., Huang, J., Charles, S. P., and Fu, G. B.: Impacts of climate change on hydrological processes in the headwater catchment of the Tarim River basin, China, Hydrol. Process., 24, 196-208, 2010.

Loorbach, D. and Rotmans, J. The practice of transition management: Examples and lessons from four distinct cases, Futures, 42, 237-246, 2010.

Marengo, J. A., Jones, R., Alves, L. M., and Valverde, M. C.: Future change of climate in South America in the late twenty-first century: intercomparison of scenarios from three regional climate models, Clim. Dynam., 35, 1073-1097, 2009.

Matonse, A. H., Pierson, D. C., Frei, A., Zion, M. S., Anandhi, A., Schneiderman, E., and Wright, B.: Investigating the impact of climate change on NewYork City's primary water supply, Climatic Change, 116, 437-456, 2013.

MIKE 11: A Modelling System for Rivers and Channels: Reference Manual, DHI Water \& Environment, Denmark, 524 pp., 2009.

Milly, P. C. D., Dunne, K. A., and Vecchia, A. V.: Global pattern of trends in streamflow and water availability in a changing climate, Nature, 438, 347-350, 2005.

Milly, P. C. D., Betancourt, J., Falkenmark, M., Hirsch, R. M., Kundzewicz, Z. W., Lettenmaier, D. P., and Stouffer, R. J.: Stationarity is dead: whither water management?, Science, 319, 573-574, doi:10.1126/science.1151915, 2008.

Montenegro, S. M. G. L. and Ragab, R.: Impact of possible climate and land use changes in the semiarid regions: a case study from North Eastern Brazil, J. Hydrol., 434, 55-68, 2012.

Mujumdar, P. P.: Climate change: a growing challenge for water management in developing countries, Water Resour. Manage., 27, 953-954, doi:10.1007/s11269-012-0223-x, 2013.
Nóbrega, M. T., Collischonn, W., Tucci, C. E. M., and Paz, A. R.: Uncertainty in climate change impacts on water resources in the Rio Grande Basin, Brazil, Hydrol. Earth Syst. Sci., 15, 585-595, doi:10.5194/hess-15-585-2011, 2011.

Pena de Andrade, J. G., Barbosa, P. S. F., Souza, L. C. A., and Makino, D. L.: Interbasin Water Transfers: The Brazilian Experience and International Case Comparisons, Water Resour. Manage., 25, 1915-1934, doi:10.1007/s11269-011-9781-6, 2011.

Pernambuco: Plano Hidroambiental da Bacia Hidrográfica do Rio Capibaribe, Tomo II - Cenários Tendenciais e Sustentáveis, Secretariat of Water and Energy Resources - SRHE, Recife, 190 pp. 2010.

Porto, R. L. L., Roberto, A. N., Schardong, A., and Mello Júnior, A. V.: Sistema de suporte a decisão para análise de sistemas de recursos hídricos, in: Métodos numéricos em recursos hídricos, edited by: Silva, R. C. V., ABRH, Porto Alegre, 93-240, 2003.

Savenije, H. H. G., Hoekstra, A. Y., and van der Zaag, P.: Evolving water science in the Anthropocene, Hydrol. Earth Syst. Sci., 18, 319-332, doi:10.5194/hess-18-319-2014, 2014.

Scott, C. A., Meza, F. J., Varady, R. G., Tiessen, H., McEvoy, J., Garfin, G. M., Wilder, M., Farfán, L. M., Pineda Pablos, N., and Montaña, N.: Water security and adaptive management in the arid Americas, Ann. Assoc. Am. Geogr., 103, 280-289, doi:10.1080/00045608.2013.754660, 2013.

Short, M. D., Peirson, W. L., Peters, G. M., and Cox, R. J.: Managing adaptation of urban water systems in a changing climate, Water Resour. Manage., 26, 1953-1981, 2012.

Shourian, M., Mousavi, S. J., and Tahershamsi, A.: Basin-wide water resources planning by integrating PSO algorithm and MODSIM, Water Resour. Manage., 22, 1347-1366, 2008.

Sugawara, M.: Tank Model, in: Computer Models of Watershed Hydrology, edited by: Singh, V. P., Water Resources Publications, Highlands Ranch, Colorado, USA, 165-214, 2012.

Thompson, S. E., Sivapalan, M., Harman, C. J., Srinivasan, V., Hipsey, M. R., Reed, P., Montanari, A., and Blöschl, G.: Developing predictive insight into changing water systems: useinspired hydrologic science for the Anthropocene, Hydrol. Earth Syst. Sci., 17, 5013-5039, doi:10.5194/hess-17-50132013, 2013.

Van der Brugge, R., Rotmans, J., and Loorbach, D.: The transition in Dutch water management, Reg. Environ. Change, 5, 164-176, 2005.

Vaze, J., Davidson, A., Teng, J., and Podger, G.: Impact of climate change on water availability in the Macquarie-Castlereagh River Basin in Australia, Hydrol. Process., 25, 2597-2612, 2011. 